\title{
PENGUKURAN PRODUKTIVITAS MENGGUNAKAN FUNGSI COBB-DOUGLAS BERDASARKAN JAM KERJA EFEKTIF
}

\author{
Filscha Nurprihatin ${ }^{1}$, Hendy Tannady ${ }^{2}$ \\ 1,2Program Studi Teknik Industri, Universitas Bunda Mulia, Jakarta \\ e-mail: fnurprihatin@bundamulia.ac.id ${ }^{1}$, htannady @ bundamulia.ac.id $^{2}$
}

Received: December 3, 2016; Accepted: January 8, 2017

\begin{abstract}
ABSTRAK
Perusahaan yang ingin mempertahankan eksistensinya harus dapat melakukan peningkatan produktivitas dari waktu ke waktu. Penelitian ini dilakukan pada perusahaan manufaktur dengan produk sarung tangan golf yang diproduksi di salah satu perusahaan di Yogyakarta. Penelitian ini bertujuan untuk membandingkan produktivitas jumlah waktu kerja efektif pada bagian produksi pada tahun 2014 dan 2015. Pengukuran produktivitas dilakukan dengan menggunakan pendekatan fungsi Cobb-Douglas. Penelitian ini menunjukkan bahwa tingkat produktivitas tahun 2015 lebih tinggi daripada tahun 2014 dengan nilai indeks efisiensi pada tahun 2014 dan 2015 adalah sebesar 54.995,07 dan 59.873,94. Hal ini berarti bahwa penggunaan jam kerja meningkat sebesar $8,87 \%$.
\end{abstract}

Kata Kunci: Produktivitas, Jam Kerja Efektif, Cobb-Douglas, Indeks Efisiensi.

\begin{abstract}
From time to time the increasing productivity needs to be done to maintain the existence of a company. This research was conducted at a golf glove manufacturing company in Yogyakarta. This study was aimed to compare the productivity of effective working time at production line in 2014 and 2015. This research was using Cobb-Douglas approach. This study shows that the level of productivity in 2015 was higher than in 2014 with the value of the efficiency index in 2014 and 2015 are 54995.07 and 59873.94 respectively. This means that the usage of working hours was increased by $8.87 \%$.
\end{abstract}

Keywords: Productivity, Effective Working Hours, Cobb-Douglas, Efficiency Index

\section{PENDAHULUAN}

Dalam dunia industri manufaktur, perusahaan senantiasa mengutamakan efisiensi dalam berbagai bidang untuk meningkatkan produktivitas kerja dan profit dari produk yang dihasilkan. Seiring dengan itu, kebutuhan konsumen semakin bertambah dalam hal kualitas dan kuantitas yang memungkinkan semakin ketat persaingan antar industri manufaktur. Perilaku konsumen sangat berperan penting sebagai feedback dari produk sekaligus pelayanan yang diberikan. Perusahaan yang ingin mempertahankan eksistensinya harus dapat melakukan peningkatan produktivitas dari waktu ke waktu.

Perusahaan idealnya memperhatikan dan senantiasa mengatur tingkat produktivitas kerja tetap pada tingkat tertentu yang diinginkan. Hal ini dilakukan khususnya pada bagian produksi karena waktu kerja yang ditetapkan adalah delapan jam efektif dalam satu hari kerja normal. Setiap operator pasti akan mengalami kejenuhan yang akhirnya mengalami penurunan etos kerja, baik dalam jangka waktu pendek maupun dalam jangka waktu panjang. Setiap penurunan kinerja pada operator akan menimbulkan gangguan terhadap proses kerja berikutnya, material dan biaya.

Penelitian tentang produktivitas telah dilakukan dengan berbagai metode, antara lain metode pengurangan pemborosan, Mosaic Embedding Iron Ore Sintering (MEBIOS), pengurangan waktu siklus, metode 5S (Seiri, Seiton, Seiso, Seiketsu, 
Shitsuke), metode lean deployment dan studi waktu, metode regresi linier berganda, metode Overall Performance Effectiveness (OPE), metode Fuzzy Decision Making Trial dan Laboratory (DEMATEL) dan Analytic Network (ANP), metode Data Envelopment Analysis (DEA) dan Cappock Index Instability (CII) serta metode perancangan ulang alat kerja. Metode pengurangan pemborosan dipakai oleh Islam dkk., (2013) untuk meminimasi jumlah rework dan meningkatkan produktivitas pada industri pakaian. Kamijo dkk., (2013) melakukan studi untuk meningkatkan produktivitas bijih besi dengan meningkatkan permeabilitas bijih besi dengan menggunakan MEBIOS. Dengan mengurangi waktu siklus, Mandwe (2013) mampu meningkatkan utilisasi resource dan mesin pada produksi crankshaft. Metode 5S dilakukan pada industri manufaktur untuk meningkatkan produktivitas (Pasale dan Bagi, 2013). Studi yang dilakukan oleh Kulkani dkk., (2014) menurunkan waktu set up dengan metode lean deployment dan studi kerja. Wirawan dkk., (2014) mengetahui pengaruh banyaknya rumpun, benih, pupuk, pestisida dan serangan hama terhadap produktivitas padi dengan regresi linier berganda. Peningkatan performansi mesin injeksi molding dilakukan dengan meningkatkan proses set up menggunakan metode OPE (Low dkk., 2014). Metode fuzzy DEMATEL dan ANP digunakan oleh Kurniawati dan Yuliando (2015) untuk mengidentifikasi faktor yang berpengaruh dalam peningkatan produktivitas pada Usaha Kecil dan Menengah (UKM) produksi makanan. Pada industri penangkapan ikan, Wardono dkk., (2015) menggunakan DEA dan CII untuk mengetahui faktor produktivitas total dan indeks ketidakstabilan. Kristianto dan Widodo (2015) melakukan riset dengan merancang ulang alat untuk meminimasi waktu proses dan konsumsi energi. Penelitian-penelitian di atas tidak menggunakan fungsi produksi CobbDouglas, sedangkan penelitian ini menggunakan fungsi produksi CobbDouglas untuk mengukur produktivitas.
Penelitian yang menggunakan fungsi produksi Cobb-Douglas telah dilakukan dengan tujuan bukan untuk mengukur produktivitas. Riset Indrawati dkk., (2014) bertujuan untuk optimasi harga internet. Metode Cobb-Douglas dikombinasikan dengan metode Habberstad oleh Supriyanto dkk., (2014) pada pabrik pengecoran logam. Ningsih dkk., (2014) mempunyai tujuan untuk mengetahui capaian efisiensi teknik dan ekonomis pada usaha tani. Studi Graha dan Yuliawati (2015) bertujuan untuk mengetahui pengaruh kearifan lokal dan perubahan iklim pada produksi padi. Risetriset di atas tidak bertujuan untuk mengukur produktivitas.

Studi tentang produktivitas dengan menggunakan Cobb-Douglas dilakukan dengan produk tangible dan intangible. Produk tangible yang dimaksud adalah produk dalam bidang pertanian, peternakan dan manufaktur. Sedangkan produk intangible yang dimaksud adalah produk pelayanan.

Penelitian tentang produktivitas dengan menggunakan Cobb-Douglas yang dilakukan pada produk intangible dilakukan oleh Thomas (2013). Penelitian Thomas (2013) dilakukan untuk mengukur produktivitas sekolah. Faktor-faktor yang menjadi variabel bebasnya adalah kompetensi guru, budaya organisasi, pembiayaan pendidikan, kepemimpinan Kepala Sekolah, kepemimpinan Komite Sekolah dan mutu.

Riset yang menggunakan Cobb-Douglas untuk mengukur produktivitas pada produk tangible terdiri dari bidang pertanian, peternakan dan manufaktur. Pada bidang pertanian, penelitian sudah dilakukan oleh Mayashinta dan Firdaus (2013), Suardana dkk., (2013), Nugroho (2015), Sumarno dkk., (2015) dan Widiyawati dan Setiawan (2015). Mayashinta dan Firdaus (2013) mengkombinasikan Cobb-Douglas dan Error Correction Model (ECM). Studi oleh Suardana dkk., (2013) menggunakan variabel bebas antara lain luas lahan, benih, pupuk, tenaga kerja dan pengalaman dengan 
produl gabah kering. Riset dengan produk jagung dilakukan oleh Nugroho (2015), Sumarno dkk., (2015) dan Widiyawati dan Setiawan (2015). Nugroho (2015) meneliti dengan variabel bebas berupa luas lahan, jumlah benih, jumlah pupuk, jumlah pestisida, jumlah tenaga kerja dan biaya lainlain. Sementara itu, Sumarno dkk., (2015) menggunakan variabel bebas antara lain luas lahan, jumlah benih, penggunaan pupuk urea, penggunaan pupuk phonska dan jumlah tenaga kerja. Studi oleh Widiyawati dan Setiawan (2015) mengelaborasi CobbDouglas dan Principal Component Regression (PCR) dengan variabel bebas berupa harga jagung, upah kerja dan penggunaan pupuk urea.

Di bidang peternakan, penelitian dilakukan oleh Andriyanto dkk., (2013) dan Sujarwo dkk., (2015). Riset Andriyanto dkk., (2013) dilakukan untuk mengetahui pengaruh tenaga kerja, pupuk, pakan dan padat penyebaran terhadap produktivitas udang. Studi oleh Sujarwo dkk., (2015) membahas tentang pengaruh hijauan, konsentrat, tenaga kerja dan jumlah sapi laktasi terhadap pendapatan peternak. Riset-riset tersebut tidak dilakukan pada industri manufaktur.

Penelitian yang dilakukan di industri manufaktur dilakukan oleh Devi dkk., (2013) dan Salam dan Prishardoyo (2016). Devi dkk., (2013) dilakukan untuk mengetahui pengaruh tenaga kerja dan mesin terhadap hasil produksi pada industri obat. Riset yang dilakukan oleh Salam dan Prishardoyo (2016) mengkaji pengaruh angkatan kerja dengan pendidikan tinggi, angkatan kerja dengan pendidikan rendah, modal dan upah terhadap produktivitas industri pengolahan. Studi-studi di atas tidak mempertimbangkan jam kerja efektif operator kerja sedangkan penelitian ini memperhitungkan faktor jam kerja efektif.

Karakteristik unik dari permasalahan pada penelitian ini adalah jumlah output bernilai konstan sepanjang tahun, sementara jumlah input berupa jam kerja efektif bersifat fluktuatif. Data yang diperlukan adalah jumlah produksi per bulan dan jumlah waktu kerja efektif dalam setiap bulannya. Dengan penelitian ini, dapat diketahui apakah jumlah waktu kerja efektif pada bagian produksi sudah produktif untuk menghasilkan produk akhir sarung tangan yang tentunya sesuai dengan spesifikasi yang sudah ditentukan oleh konsumen sendiri.

\section{TINJAUAN PUSTAKA \\ 2.1 Teori Produktivitas}

Definisi produktivitas terus berkembang sejalan dengan perkembangan manusia. Istilah produktivitas sangat berkaitan dengan produksi (Mahendra, 2014), sehingga seringkali produktivitas hanya dilihat sebelah mata saja yaitu pada jumlah produksi. Produksi adalah suatu aktivitas untuk menghasilkan barang dan/atau jasa. Sedangkan produktivitas adalah rasio antara output hasil produksi dibanding dengan input produksi.

Produksi tidak dapat dipisahkan dengan efektivitas dan efisiensi. Efisiensi adalah ukuran yang menunjukkan penggunaan sumber-sumber daya yang digunakan dalam proses produksi. Sedangkan efektivitas adalah ukuran derajat pencapaian output dari sistem produksi. Jadi efisiensi berkaitan dengan penggunaan resources, sedangkan efektivitas berkaitan dengan performansi. Maka produktivitas dapat dirumuskan pada persamaan (1) sebagai berikut:

$$
\begin{aligned}
& \text { Produktivitas }=\frac{\text { output yang dihasilkan }}{\text { input yang digunakan }} \\
& =\frac{\text { pencapaian tujuan }}{\text { penggunaan sumber-sumber daya }} \\
& =\frac{\text { efektivitas pelaksanaan tugas }}{\text { efisiensi penggunaan sumber-sumber daya }} \\
& =\frac{\text { efektivitas }}{\text { efisiensi }}
\end{aligned}
$$

Program produktivitas merupakan suatu proses yang kontinyu atau proses yang berlangsung secara berkesinambungan. Siklus produktivitas mengharuskan tahap pengukuran produktivitas dahulu kemudian ke tahap selanjutnya, yaitu evaluasi produktivitas, perencanaan produktivitas dan peningkatan produktivitas. Pengukuran produktivitas mensyaratkan adanya aktivitas pencarian data yang menyangkut obyek yang diukur. Evaluasi mencakup kegiatan 
menilai menjadi ukuran-ukuran tertentu dan menyimpulkan kondisi obyek yang diukur. Evaluasi juga membandingkan antara produktivitas riil dengan produktivitas yang diharapkan. Perencanaan produktivitas mencakup kegiatan mendesain kegiatan produksi atau aktivitas usaha. Peningkatan produktivitas merupakan implementasi dari perencanaan produktivitas pada aktivitas produksi. Peningkatan produktivitas ini menyangkut pula pada faktor pengendalian produktivitas.

\subsection{Pengertian Fungsi Produksi}

Mahendra (2014) menjelaskan bahwa fungsi produksi adalah hubungan diantara faktorfaktor produksi dan tingkat produksi yang diciptakannya. Tujuan dari kegiatan produksi adalah memaksimalkan jumlah ariabel yang dijelaskan (output) dengan sejumlah variabel yang menjelaskan (input) tertentu (Mahendra, 2014). Faktor input tetap terdiri dari mesin dan peralatan, sedangkan faktor input berubah terdiri dari bahan mentah dan tenaga kerja.

\subsection{Fungsi Produksi Eksponensial (Cobb-Douglas)}

Bentuk fungsional Cobb-Douglas dari fungsi produksi secara umum digunakan untuk mempresentasikan hubungan dari input ke output. Fungsi produksi CobbDouglas adalah suatu fungsi atau persamaan yang melibatkan dua atau lebih variabel, dimana variabel dependent disimbolkan dengan $Y$ dan variabel $X$ disebut dengan variabel independent. Hubungan antara variabel $Y$ dan $X$ dapat diselesaikan dengan cara regresi dimana variasi dari $Y$ akan dipengaruhi oleh variasi dari $X$. Dengan demikian, aturan pada garis regresi juga berlaku pada fungsi Cobb-Douglas.

Fungsi produksi eksponensial ini dapat berbeda satu sama lain tergantung pada ciri data yang ada, tetapi secara umum fungsi produksi eksponensial ini dituliskan pada persamaan (2) sebagai berikut:

$Y=a X^{b}$
Secara matematis, fungsi Cobb Douglas dapat dituliskan seperti persamaan (3) berikut ini (Wang dan Fu, 2013):

$Y=a X_{1}^{b 1} X_{2}^{b 2} \ldots X_{i}^{b i} \ldots X_{n}^{b n} e^{n}$

Bila fungsi Cobb Douglas tersebut dinyatakan dengan hubungan $Y$ dan $X$, maka hubungan tersebut ditunjukkan oleh persamaan (4).

$Y=f\left(X_{1}, X_{2}, \ldots X_{i}, \ldots X_{n}\right)$

dimana:

$Y \quad=$ variabel yang dijelaskan

$X \quad=$ variabel yang menjelaskan

$a, b \quad=$ besaran yang akan diduga

$u \quad=$ galat (disturbance term)

$e \quad=$ logaritma natural, $e=2,718$

Untuk memudahkan pendugaan terhadap persamaan di atas, maka persamaan tersebut diubah menjadi bentuk linear berganda dengan cara melogaritmakan persamaan tersebut. Persamaan di atas dituliskan kembali pada persamaan (5) dan (6) untuk menjelaskan hal tersebut, yaitu (Chen, 2012):

$Y=f\left(X_{1}, X_{2}\right)$

$Y=a X_{1}^{b 1} X_{2}^{b 2} e^{n}$

Logaritma dari persamaan (5) dan (6) di atas ditulis pada persamaan (7):

$\log Y=\log a+b_{1} \log X_{1}+b_{2} \log X_{2}+\log$ $u$

Persamaan (7) hasil logaritma di atas dapat dengan mudah diselesaikan dengan cara regresi berganda. Pada persamaan tersebut terlihat bahwa nilai $b_{1}$ dan $b_{2}$ adalah tetap walaupun variabel yang terlibat telah dilogaritmakan. Hal ini dapat dimengerti karena $b_{1}$ dan $b_{2}$ pada fungsi Cobb Douglas adalah sekaligus menunjukkan elastisitas $X$ terhadap $Y$.

Karena penyelesaian fungsi Cobb Douglas selalu dilogaritmakan dan diubah bentuk fungsinya menjadi fungsi linear, maka ada beberapa persyaratan yang harus dipenuhi sebelum menggunakan fungsi Cobb Douglas, antara lain:

1. Tidak ada nilai pengamatan yang bernilai nol, sebab logaritma dari nol adalah suatu 
bilangan yang besarnya tidak diketahui (infinite).

2. Dalam fungsi produksi perlu asumsi bahwa tidak ada perbedaan teknologi pada tiap pengamatan (non-neutral difference in the respectives technologies).

3. Variabel input berada pada perfect competition.

4. Faktor-faktor lain yang tidak tercakup pada model seperti iklim sudah diperhitungkan dalam $u$.

Fungsi Cobb Douglas merupakan salah satu bentuk fungsi produksi yang paling banyak digunakan dalam analisis produktivitas. Beberapa alasan praktis yang membuat fungsi Cobb Douglas sering dipergunakan adalah:

1. Bentuk fungsi produksi Cobb Douglas bersifat sederhana dan mudah dalam penerapannya.

2. Fungsi produksi Cobb Douglas mampu menggambarkan keadaan skala hasil (return to scale) apakah sedang meningkat, tetap atau menurun.

3. Koefisien-koefisien fungsi produksi Cobb Douglas secara langsung menggambarkan elastisitas produksi dari setiap input yang dipergunakan dan dipertimbangkan untuk dikaji dalam fungsi produksi Cobb Douglas.

4. Koefisien intersep dari fungsi produksi Cobb Douglas merupakan indeks efisiensi produksi yang secara langsung menggambarkan efisiensi penggunaan input dalam menghasilkan output dari sistem produksi yang sedang dikaji.

Bentuk umum dari fungsi produksi Cobb Douglas ditulis pada persamaan (8) sebagai berikut:
$Q=\delta I^{\alpha}$

dimana:

$Q \quad=$ output

$I \quad=$ input

$\delta \quad=$ indeks efisiensi penggunaan input

$\alpha \quad=$ elastisitas produksi dari input yang digunakan

Berdasarkan rumusan pada persamaan (8) di atas dapat disimpulkan bahwa semakin besar nilai $\delta$ dalam fungsi produksi Cobb Douglas, maka indeks efisiensi produksi semakin tinggi yang berarti pula bahwa proses transformasi nilai tambah dari input menjadi output telah menjadi semakin efisien.

Akhirnya substitusi elastisitas yang baru ini membuktikan bahwa perubahan terknologi dapat merubah produktivitas, pola kerja dan faktor-faktor yang mempengaruhi efektivitas.

\section{METODOLOGI PENELITIAN}

Data jumlah produksi pada tahun 2014 dan 2015 dijelaskan pada Tabel 1 dan Tabel 2.

Pengukuran produktivitas dengan menggunakan pendekatan fungsi CobbDouglas dapat dilakukan dengan langkahlangkah sebagai berikut:

1. Menghitung rasio produktivitas.

Rasio produktivitas dapat dihitung dengan menggunakan persamaan (9) sebagai berikut:

Rasio produktivitas $=\frac{\text { Jumlah Produksi }}{\text { Jam Kerja }}(9)$

Maka, rasio produktivitas kerja pada tahun 2014 dan 2015 dapat diperoleh sebagaimana ditunjukkan pada Tabel 3 dan Tabel 4.

Tabel 1. Data Jumlah Produksi dan Jumlah Jam Kerja Periode Tahun 2014

\begin{tabular}{|lrr}
\hline \multicolumn{1}{c}{ Bulan } & Jumlah Produksi (Q) (unit) & Jam Kerja (L) (jam) \\
\hline Januari & 55.000 & 117.440 \\
\hline Februari & 55.000 & 117.120 \\
\hline Maret & 55.000 & 126.672 \\
\hline April & 55.000 & 110.230 \\
\hline Mei & 55.000 & 123.201 \\
\hline Juni & 55.000 & 127.368 \\
\hline Juli & 55.000 & 125.904 \\
\hline
\end{tabular}


ISSN: 1979-1720 Journal of Industrial Engineering and Management Systems

Vol. 10, No. 1, February 2017

\begin{tabular}{|lrr|}
\hline \multicolumn{1}{c}{ Bulan } & Jumlah Produksi (Q) (unit) & Jam Kerja (L) (jam) \\
\hline Agustus & 55.000 & 121.075 \\
\hline September & 55.000 & 125.216 \\
\hline Oktober & 55.000 & 117.440 \\
\hline November & 55.000 & 127.020 \\
\hline Desember & 55.000 & 118.800 \\
\hline
\end{tabular}

Tabel 2. Data Jumlah Produksi dan Jumlah Jam Kerja Periode Tahun 2015

Bulan Jumlah Produksi (Q) (unit) Jam Kerja (L) (jam)

\begin{tabular}{lll}
\hline Januari & 60.000 & 187.050 \\
\hline Februari & 60.000 & 184.320 \\
\hline Maret & 60.000 & 196.245 \\
\hline April & 60.000 & 188.672 \\
\hline Mei & 60.000 & 195.978 \\
\hline Juni & 60.000 & 191.065 \\
\hline Juli & 60.000 & 204.330 \\
\hline Agustus & 60.000 & 195.294 \\
\hline September & 60.000 & 192.390 \\
\hline Oktober & 60.000 & 184.500 \\
\hline November & 60.000 & 202.940 \\
\hline Desember & 60.000 & 184.912 \\
\hline
\end{tabular}

Tabel 3. Rasio Produktivitas Tahun 2014

\begin{tabular}{lrrc}
\multicolumn{1}{c}{ Bulan } & Jumlah Produksi (Q) (unit) & Jam Kerja (L) (jam) & \multicolumn{1}{c}{ Rasio } \\
\hline Januari & 60.000 & 187.050 & 0,468324 \\
\hline Februari & 60.000 & 184.320 & 0,469604 \\
\hline Maret & 60.000 & 196.245 & 0,434192 \\
\hline April & 60.000 & 188.672 & 0,498957 \\
\hline Mei & 60.000 & 195.978 & 0,446425 \\
\hline Juni & 60.000 & 191.065 & 0,431820 \\
\hline Juli & 60.000 & 204.330 & 0,436841 \\
\hline Agustus & 60.000 & 195.294 & 0,454264 \\
September & 60.000 & 192.390 & 0,439241 \\
\hline Oktober & 60.000 & 184.500 & 0,468324 \\
\hline November & 60.000 & 202.940 & 0,433003 \\
Desember & 60.000 & 184.912 & 0,462963
\end{tabular}

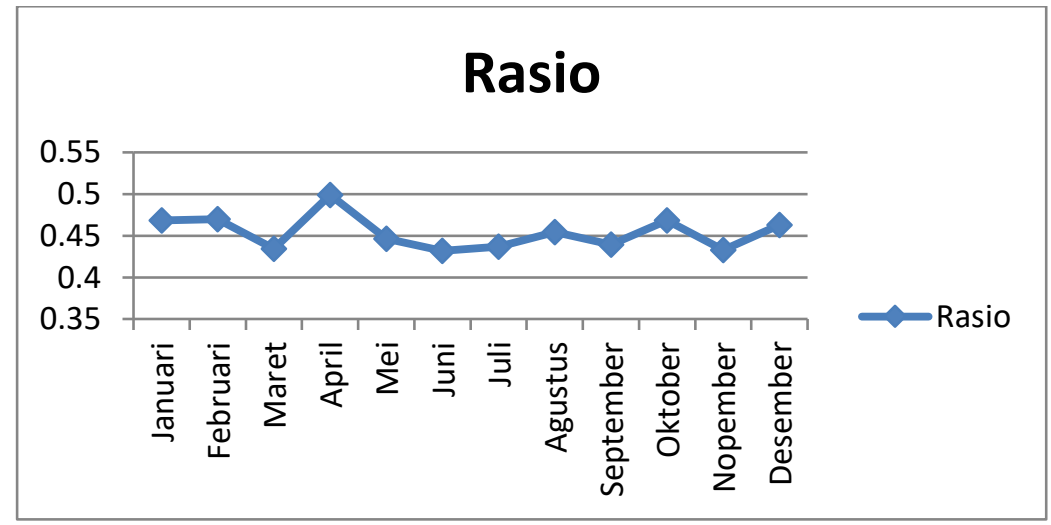

Gambar 1. Grafik Rasio Produktivitas Tahun 2014 
ISSN: 1979-1720 Journal of Industrial Engineering and Management Systems

Vol. 10, No. 1, February 2017

Tabel 4. Rasio Produktivitas Tahun 2015

\begin{tabular}{|lrrc|}
\hline \multicolumn{1}{c}{ Bulan } & Jumlah Produksi $(\mathbf{Q})(\mathbf{u n i t})$ & Jam Kerja (L) (jam) & Rasio \\
\hline Januari & 60.000 & 187.050 & 0,320770 \\
\hline Februari & 60.000 & 184.320 & 0,325521 \\
\hline Maret & 60.000 & 196.245 & 0,305740 \\
\hline April & 60.000 & 188.672 & 0,318012 \\
\hline Mei & 60.000 & 195.978 & 0,306157 \\
\hline Juni & 60.000 & 191.065 & 0,314029 \\
\hline Juli & 60.000 & 204.330 & 0,293643 \\
\hline Agustus & 60.000 & 195.294 & 0,307229 \\
\hline September & 60.000 & 192.390 & 0,311867 \\
\hline Oktober & 60.000 & 184.500 & 0,325203 \\
\hline November & 60.000 & 202.940 & 0,295654 \\
\hline Desember & 60.000 & 184.912 & 0,324479 \\
\hline
\end{tabular}

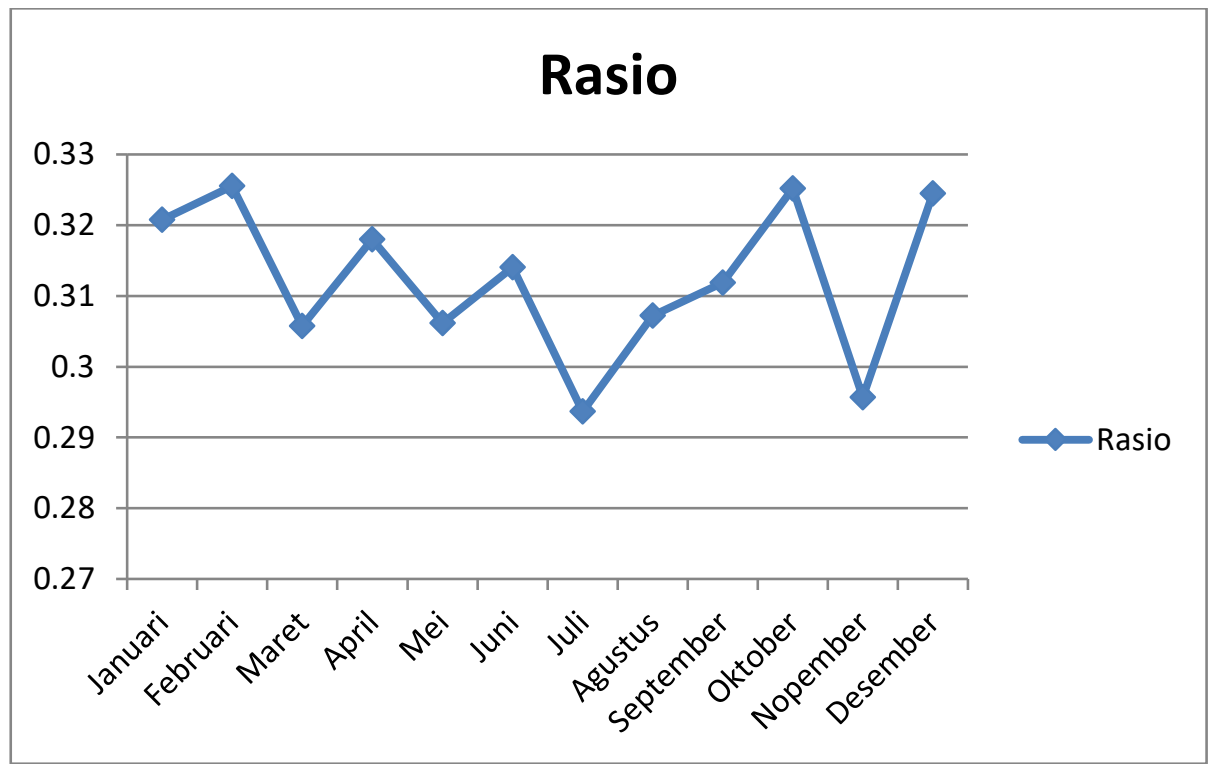

Gambar 2. Grafik Rasio Produktivitas Tahun 2015

Rasio produktivitas selama tahun 2014 terlihat pada Gambar 1, sedangkan pada Gambar 2 ditunjukkan bahwa rasio produktivitas selama tahun 2014 berbeda-beda. Hal ini disebabkan oleh perbedaan total jam kerja. Total jam kerja sangat dipengaruhi hari libur, baik hari libur internal maupun hari libur nasional. Total jam kerja juga dipengruhi oleh jam kerja normal maupun jam kerja lembur. Rasio produktivitas selama tahun 2015 terlihat pada Gambar 2.

2. Menentukan logaritma natural input dan output.

Data jumlah output dan input yang terdapat pada pengolahan data ditransformasikan ke dalam logaritma natural (ln) seperti pada Tabel 5 dan Tabel 6.

3. Melakukan analisis regresi linier logaritma natural.

Data yang telah ditransformasikan ke dalam bentuk logaritma natural (ln) kemudian digunakan untuk menghitung koefisien-koefisien fungsi produksi Cobb-Douglas dengan menggunakan analisis regresi linier logaritma. Perhitungan analisis regresi linier logaritma disajikan pada Tabel 7 dan Tabel 8. 
ISSN: 1979-1720 Journal of Industrial Engineering and Management Systems Vol. 10, No. 1, February 2017

Tabel 5. Data Logaritma Natural Produksi Sarung Tangan Tahun 2014

\begin{tabular}{lrrrc}
\hline \multicolumn{1}{c}{ Bulan } & Jumlah Produksi (Q) (unit) & Jam Kerja (L) (jam) & In Q & In L \\
\hline Januari & 55.000 & 117.440 & 10,91509 & 11,67368 \\
\hline Februari & 55.000 & 117.120 & 10,91509 & 11,67095 \\
\hline Maret & 55.000 & 126.672 & 10,91509 & 11,74936 \\
\hline April & 55.000 & 110.230 & 10,91509 & 11,61032 \\
\hline Mei & 55.000 & 123.201 & 10,91509 & 11,72157 \\
\hline Juni & 55.000 & 127.368 & 10,91509 & 11,75484 \\
\hline Juli & 55.000 & 125.904 & 10,91509 & 11,74327 \\
\hline Agustus & 55.000 & 121.075 & 10,91509 & 11,70417 \\
\hline September & 55.000 & 125.216 & 10,91509 & 11,73780 \\
\hline Oktober & 55.000 & 117.440 & 10,91509 & 11,67368 \\
\hline November & 55.000 & 127.020 & 10,91509 & 11,75210 \\
\hline Desember & 55.000 & 118.800 & 10,91509 & 11,68520 \\
\hline
\end{tabular}

Tabel 6. Data Logaritma Natural Produksi Sarung Tangan Tahun 2015

Bulan Jumlah Produksi (Q) (unit) $\quad$ Jam Kerja (L) (jam) $\ln Q \quad \ln \mathbf{L}$

\begin{tabular}{lllll}
\hline Januari & 60.000 & 187.050 & 11,0021 & 12,13913 \\
\hline Februari & 60.000 & 184.320 & 11,0021 & 12,12443 \\
\hline Maret & 60.000 & 196.245 & 11,0021 & 12,18712 \\
\hline April & 60.000 & 188.672 & 11,0021 & 12,14777 \\
\hline Mei & 60.000 & 195.978 & 11,0021 & 12,18576 \\
\hline Juni & 60.000 & 191.065 & 11,0021 & 12,16037 \\
\hline Juli & 60.000 & 204.330 & 11,0021 & 12,22749 \\
\hline Agustus & 60.000 & 195.294 & 11,0021 & 12,18226 \\
\hline September & 60.000 & 192.390 & 11,0021 & 12,16728 \\
\hline Oktober & 60.000 & 184.500 & 11,0021 & 12,12540 \\
\hline November & 60.000 & 202.940 & 11,0021 & 12,22067 \\
\hline Desember & 60.000 & 184.912 & 11,0021 & 12,12764 \\
\hline
\end{tabular}

Tabel 7. Data untuk Analisis Regresi Linier Logaritma Natural Tahun 2014 $\begin{array}{lllll}\text { Bulan } & \ln \mathbf{Q} & \ln \mathrm{L} & (\ln \mathrm{Q})(\ln \mathrm{L}) & (\ln \mathrm{L})^{\mathbf{2}}\end{array}$

\begin{tabular}{lrrrr}
\hline Januari & 10,91509 & 11,67368 & 127,4193 & 136,2749 \\
\hline Februari & 10,91509 & 11,67095 & 127,3895 & 136,2112 \\
\hline Maret & 10,91509 & 11,74936 & 128,2453 & 138,0474 \\
\hline April & 10,91509 & 11,61032 & 126,7277 & 134,7996 \\
\hline Mei & 10,91509 & 11,72157 & 127,9420 & 137,3953 \\
\hline Juni & 10,91509 & 11,75484 & 128,3051 & 138,1762 \\
\hline Juli & 10,91509 & 11,74327 & 128,1789 & 137,9045 \\
\hline Agustus & 10,91509 & 11,70417 & 127,7520 & 136,9875 \\
\hline September & 10,91509 & 11,73780 & 128,1191 & 137,7758 \\
\hline Oktober & 10,91509 & 11,67368 & 127,4193 & 136,2749 \\
\hline November & 10,91509 & 11,75210 & 128,2752 & 138,1119 \\
\hline Desember & 10,91509 & 11,68520 & 127,5450 & 136,5438 \\
\hline Jumlah & 131 & 140 & 1.533 & 1.645 \\
\hline
\end{tabular}


Tabel 8. Data untuk Analisis Regresi Linier Logaritma Natural Tahun 2015

\begin{tabular}{lrrrr}
\multicolumn{1}{c}{ Bulan } & \multicolumn{1}{c}{$\ln \mathbf{Q}$} & \multicolumn{1}{c}{$\ln \mathbf{L}$} & \multicolumn{1}{c}{$(\ln \mathbf{Q})(\ln \mathbf{L})$} & \multicolumn{1}{c}{$(\ln \mathbf{L})^{\mathbf{2}}$} \\
\hline Januari & 11,0021 & 12,13913 & 133,5559 & 147,3585 \\
\hline Februari & 11,0021 & 12,12443 & 133,3942 & 147,0018 \\
\hline Maret & 11,0021 & 12,18712 & 134,0839 & 148,5259 \\
\hline April & 11,0021 & 12,14777 & 133,6509 & 147,5682 \\
\hline Mei & 11,0021 & 12,18576 & 134,0689 & 148,4927 \\
\hline Juni & 11,0021 & 12,16037 & 133,7896 & 147,8746 \\
\hline Juli & 11,0021 & 12,22749 & 134,5281 & 149,5116 \\
\hline Agustus & 11,0021 & 12,18226 & 134,0305 & 148,4075 \\
\hline September & 11,0021 & 12,16728 & 133,8656 & 148,0427 \\
\hline Oktober & 11,0021 & 12,12540 & 133,4049 & 147,0254 \\
\hline November & 11,0021 & 12,22067 & 134,4530 & 149,3447 \\
\hline Desember & 11,0021 & 12,12764 & 133,4295 & 147,0795 \\
\hline Jumlah & 132 & 146 & 1.606 & 1.776 \\
\hline
\end{tabular}

4. Menentukan nilai rata-rata logaritma natural output $(\overline{\ln Q})$.

Data yang terdapat pada Tabel 5 dan Tabel 6 dapat digunakan untuk menghitung nilai rata-rata logaritma natural output Tahun 2014 dan 2015. Nilai rata-rata logaritma natural output dapat dihitung dengan menggunakan persamaan (10).

$\overline{\ln Q}=\frac{\Sigma \ln Q}{n}$.

Nilai rata-rata logaritma natural output tahun 2014 dihitung dengan persamaan (11) sebagai berikut:

$\overline{\ln Q}=\frac{\Sigma \ln Q}{n}$
$=\frac{130,98106}{12}=10,915$

Nilai rata-rata logaritma natural output tahun 2015 dihitung dengan persamaan (12) sebagai berikut:

$\overline{\ln Q}=\frac{\sum \ln Q}{n}$

$=\frac{132,025}{12}=11$

5. Menentukan nilai rata-rata logaritma natural input $(\overline{\ln L})$.

Data yang terdapat pada Tabel 5 dan Tabel 6 dapat digunakan untuk menghitung nilai rata-rata logaritma natural input tahung 2014 dan 2015 . Nilai rata-rata logaritma natural input dihitung dengan persamaan (13)

$\overline{\ln L}=\frac{\Sigma \ln L}{n}$.
Nilai rata-rata logaritma natural input tahun 2014 dihitung dengan persamaan (14) sebagai berikut:

$\overline{\ln L}=\frac{\Sigma \ln L}{n}$

$=\frac{140,47694}{12}=11,706$

Nilai rata-rata logaritma natural input tahun 2015 dihitung dengan persamaan (15) sebagai berikut:

$\overline{\ln L}=\frac{\Sigma \ln L}{n}$

$=\frac{144,995}{12}=12,166$

6. Menentukan koefisien elastisitas produksi.

Data yang terdapat pada Tabel 7 dan Tabel 8 dapat digunakan untuk menghitung koefisien elastisitas produksi tahun 2014 dan 2015. Nilai koefisien elastisitas produksi dapat dihitung dengan persamaan (16) sebagai berikut:

$\beta=\frac{(n \Sigma(\ln Q \times \ln L))-(\Sigma \ln Q)(\Sigma \ln L)}{\left(n \Sigma(\ln L)^{2}-(\Sigma \ln L)^{2}\right.}$

Koefisien elastisitas produksi tahun 2014 adalah sebagai berikut:

$$
\begin{aligned}
& \beta \quad=\frac{(n \Sigma(\ln Q \times \ln L))-(\Sigma \ln Q)(\Sigma \ln L)}{\left(n \Sigma(\ln L)^{2}-\left(\sum \ln L\right)^{2}\right.} \\
& =\frac{(12 \times 1533,31824)-(130,981060 \times 140,47694)}{\left(12 \times\left(140,47694^{2}\right)\right)-1644,50286} \\
& =\frac{0,022063}{235160,95} \\
& =0,000000093 .
\end{aligned}
$$


Koefisien elastisitas produksi tahun 2015 adalah sebagai berikut:

$\beta=\frac{(n \Sigma(\ln Q \times \ln L))-(\Sigma \ln Q)(\Sigma \ln L)}{\left(n \Sigma(\ln L)^{2}-(\Sigma \ln L)^{2}\right.}$

$=\frac{(12 \times 1606,255)-(132,025 \times 145,995)}{\left(12 \times\left(145,995^{2}\right)\right)-1776,233}$

$=\frac{0,070125}{253998,247}$

$=0,000000276$.

7. Menentukan indeks efisiensi

Indeks efisiensi dapat dihitung dengan menggunakan persamaan-persamaan sebelumnya. Data yang digunakan dalam menentukan indeks efisiensi adalah data nilai rata-rata logaritma natural output, nilai rata-rata logaritma natural input dan koefisien elastisitas produksi. Indeks efisiensi dapat dihitung dengan persamaan (17) dan untuk mengetahui nilai $\delta$ dapat dilakukan dengan melakukan kalkulasi pada persamaan (18).

$\tau=\overline{\ln Q}-\beta \overline{\ln L}$

$\delta=\operatorname{anti} \ln \tau$

Indeks efisiensi tahun 2014 adalah sebagai berikut:

$\tau=\overline{\ln Q}-\beta \overline{\ln L}$

$=10,915-0,000000093 \times 11,706$

$=10,91499891$

$\delta=$ anti $\ln \tau=e^{10,91499891}=54.995,07$.

Fungsi produksi Cobb-Douglas tahun 2014 adalah

$Q=(\delta)\left(L^{\beta}\right)=(54.995,07)\left(L^{0,000000093}\right)$

Indeks efisiensi tahun 2015 adalah sebagai berikut:

$\tau=\overline{\ln Q}-\beta \overline{\ln L}$

$=11-0,000000276 \times 12,166$

$=10,99999664$

$\delta=$ anti $\ln \tau=e^{10,99999664}=59.873 .94$

Fungsi produksi Cobb-Douglas tahun 2015 adalah

$Q=(\delta)\left(L^{\beta}\right)=(59.873 .94)\left(L^{0,000000276}\right)$

\section{HASIL DAN PEMBAHASAN}

Hasil perhitungan pengolahan data secara ringkas dapat disajikan seperti pada Tabel 9.
Tabel 9. Hasil Perhitungan Fungsi Cobb-

$$
\text { Douglas }
$$

\begin{tabular}{|lc|}
\hline Tahun & Fungsi Cobb-Douglas \\
\hline $\mathbf{2 0 1 4}$ & $\mathrm{Q}=\delta . L^{\beta}=54.995,07 \cdot L^{0,000000093}$ \\
\hline $\mathbf{2 0 1 5}$ & $\mathrm{Q}=\delta . L^{\beta}=59.873,94 \cdot L^{0,000000276}$ \\
\hline
\end{tabular}

Dari output fungsi produksi Cobb-Douglas pada Tabel 11 dapat diperoleh beberapa informasi yang berkaitan dengan pengukuran produktivitas total, yaitu:

1. Indeks efisiensi input untuk menghasilkan output ( $\delta$ ) pada tahun 2014 sebesar 54,995,07 jam, sedangkan indeks efisiensi tahun 2015 sebesar 59,873,94 jam. Ini berarti bahwa penggunaan input pada tahun 2015 lebih efisien daripada tahun 2014.

2. Nilai indeks efisiensi produksi tahun $2015 \quad(\delta=59.873,94 \quad$ jam $) \quad$ apabila dibandingkan dengan indeks efisiensi tahun $2014(\delta=54.995,07$ jam $)$ sebesar: $\frac{59873,94}{54995,07}=1,088$

Dengan persentase perbandingan efisiensi produksi sebesar:

$(1,088-1) \times 100 \%=8,87 \%$.

Berdasarkan nilai indeks efisiensi di atas, maka dapat diketahui bahwa pada tahun 2015 perusahaan lebih efisien menggunakan jam kerja daripada tahun 2014. Dengan demikian performansi produktivitas total pada tahun 2015 meningkat sebesar $8,87 \%$ dalam satu tahun terakhir.

\section{KESIMPULAN DAN SARAN}

Dari analisis hasil yang diperoleh, maka penulis menarik kesimpulan bahwa:

1. Tingkat produktivitas tahun 2015 lebih tinggi daripada tingkat produktivitas tahun 2014.

2. Kenaikan tingkat produktivitas dipengaruhi oleh penggunaan input (jam kerja) yang efisien. Nilai indeks efisiensi produksi pada tahun 2014 sebesar 54.995,07 jam, sedangkan indeks efisiensi tahun 2015 sebesar 59.873,94 jam. Ini berarti bahwa penggunaan jam kerja tahun 2015 meningkat $8,87 \%$ dari tahun 2014. 
Tahun 2015 telah menunjukkan bahwa tingkat produktivitas perusahaan meningkat. Oleh sebab itu sebaiknya perusahaan berusaha untuk mempertahankan tren tersebut atau bahkan meningkatkan tingkat produktivitas perusahaan. Adapun beberapa alternatif yang dapat dilakukan untuk mempertahankan dan meningkatkan tingkat produktivitas perusahaan antara lain:

1. Melakukan pengkajian terhadap perkembangan produktivitas terhadap elemen kerja lain yang terkait langsung dalam proses produksi.

2. Perusahaan sebaiknya memperluas daerah pemasaran dan meningkatkan promosi untuk meningkatkan jumlah order agar tingkat produktivitas menjadi meningkat.

\section{DAFTAR PUSTAKA}

1. Andriyanto, F., Efani, A., dan Riniwati, H. (2013). "Analisis Faktor-Faktor Produksi Usaha Pembesaran Udang Vanname (Litopenaeus Vannamei) di Kecamatan Paciran Kabupaten Lamongan Jawa Timur; Pendekatan Fungsi Cobb-Douglass". Economic and Social of Fisheries and Marine Journal, Vol. 1 No. 1, pp. 82-96.

2. Chen, B. (2012). "Classification of hHomogeneous Production Functions with Constant Elasticity of Substitution". Tamkang Journal of Mathematics, Vol. 43 No. 2, pp. 321-328.

3. Devi, A.P., Fudholi, A., dan Saleh, S. (2013). "Analisis Efektivitas Produksi Obat Kaplet Floxad dan Sirup Lafidril: Studi Kasus di Lembaga Farmasi Direktorat Kesehatan Angkatan Darat Bandung”. Jurnal Manajemen dan Pelayanan Farmasi, Vol. 3 No. 1, pp. 7079.

4. Graha, A.A.W. dan Yuliawati. (2015). "Potret Kearifan Lokal, Perubahan Iklim dan Penggaruhnya terhadap Produktivitas Padi Sawah di Salatiga". Jurnal Agric, Vol. 27 No. 1 \& No.2, pp. 50-59.
5. Indrawati, Irmeilyana, Puspita, F.M., dan Lestari, M.P. (2014). "Cobb-Douglass Utility Function in Optimizing the Internet Pricing Scheme Model". Telkomnika, Vol. 12 No. 1, pp. 227-240.

6. Islam, M.M., Khan, A.M., dan Khan, M.M.R. (2013). "Minimization of Reworks in Quality and Productivity Improvement in the Apparel Industry". International Journal of Engineering and Applied Sciences, Vol. 1 No. 4, pp. 147164.

7. Kamijo, C., Hara, M., Yamaguchi, Y., Yoshikawa, M., Kano, J., Matsumura, M., dan Kawaguchi, T. (2013). "Technology for Productivity Improvement of Sintering Based on Designing of Composite Granulation and Bed Structure of Sinter Mixture". The Iron and Steel Institute of Japan (ISIJ) International, Vol. 53 No. 9, pp. 14971502.

8. Kristanto, A. dan Widodo, S.C. (2015). "Perancangan Ulang Alat Perontok Padi yang Ergonomis untuk Meningkatkan Produktivitas dan Kualitas Kebersihan Padi”. Jurnal Ilmiah Teknik Industri, Vol. 14 No. 1, pp. 78-85.

9. Kulkarni, P.P., Kshire, S.S., dan Chandratre, K.V. (2014). "Productivity Improvement Through Lean Deployment \& Work Study Methods". International Journal of Research in Engineering and Technology, Vol. 3 Issue 2, pp. 429-434.

10.Kurniawati, D. dan Yuliando, H. (2015). "Productivity Improvement of Small Scale Medium Enterprises (SMEs) on Food Products: Case at Yogyakarta Province, Indonesia". The 2014 International Conference on Agroindustry (ICoA): Competitive and Sustainable Agroindustry for Human Welfare. Agriculture and Agricultural Science Procedia 3, pp. 189-194.

11.Low, S-N., Chong, S-H., Sim, H-Y., Razalli, S., dan Kamaruddin, S. (2014). "Measurement of Overall Performance Effectiveness in Setup Improvement". Journal of Industrial Engineering, pp. 17. 
12.Mahendra, A.D. (2014). Analisis Pengaruh Pendidikan, Upah, Jenis Kelamin, Usia dan Pengalaman Kerja terhadap Produktivitas Tenaga Kerja. Skripsi Program Sarjana Ilmu Ekonomi Studi Pembangunan Fakultas Ekonomika dan Bisnis Universitas Diponegoro.

13.Mandwe, P. (2013). "Productivity Improvement of Crankshaft". International Journal of Scientific \& Technology Research, Vol. 2 Issue 7, pp. 207-209.

14.Mayashinta, W. dan Firdaus, M. (2013). "Faktor-Faktor yang Mempengaruhi Total Factor Productivity Industri Pertanian Indonesia Periode 1981-2010”. Jurnal Manajemen \& Agribisnis, Vol. 10 No. 2, pp. 90-97.

15.Ningsih, I.M., Dwiastuti, R., dan Suhartini. (2014). "Analisis Efisiensi Ekonomis Usahatani Kedelai Dalam Rangka Mendukung Keanekaragaman Pangan (Kasus di Desa Mlorah, Kecamatan Rejoso, Kabupaten Nganjuk)". Jurnal Habitat, Vol. 25 No. 3, pp. 183-191.

16.Nugroho, B.A. (2015). "Analisis Fungsi Produksi dan Efisiensi Jagung di Kecamatan Patean Kabupaten Kendal". Journal of Economics and Policy (JEJAK), Vol. 8 No. 2, pp. 163-177.

17.Pasale, R.A. dan Bagi, J.S. (2013). "5S Strategy for Productivity Improvement: A Case Study". Paripex-Indian Journal of Research, Vol. 2 Issue 3, pp. 151-153.

18.Salam, S.A. dan Prishardoyo, B. (2016). "Pengaruh Human Capital Spillover Effects terhadap Produktivitas Industri Pengolahan Kawasan Kedungsepur". Economics Development Analysis Journal, Vol. 5 No. 2, pp. 165-173.

19.Suardana, P.A., Antara, M., dan Alam, M.N. (2013). "Analisis Produksi dan Pendapatan Usahatani Padi Sawah dengan Pola Jajar Legowo di Desa Laantula Jaya Kecamatan Witaponda Kabupaten Morowali”. E-Jurnal Agrotekbis, Vol. 1 No. 5, pp. 477-484.
20.Sujarwo, A., Priyono, dan Arifin, H.D. (2015). “Analisis Faktor Produksi dan Pendapatan Usaha Ternak Sapi Perah Desa Hargobinangun Kecamatan Pakem Kabupaten Sleman". Jurnal Surya Agritama, Vol. 4 No. 1, pp. 11-22.

21.Sumarno, J., Harianto, dan Kusnadi, N. (2015). "Peningkatan Produksi dan Efisiensi Usahatani Jagung Melalui Penerapan Pengelolaan Tanaman Terpadu (PTT) di Gorontalo". Jurnal Manajemen \& Agribisnis, Vol. 12 No. 2, pp. 79-91.

22.Supriyanto, F.T., Yusuf, M., dan Wisnubroto, P. (2014). "Analisis Produktivitas Menggunakan Metode Cobb Douglas dan Metode Habberstad (Pospac) (Studi Kasus di Pabrik Pengecoran Logam "PT Baja Kurnia")". Jurnal Rekavasi, Vol. 2 No. 1, pp. 25-32.

23.Thomas, P. (2013). "Penerapan Model Produktivitas SMKN Bisnis-Manajemen di Kota Semarang". Jurnal Pendidikan Ekonomi Dinamika Pendidikan, Vol. 8 No. 1, pp. 1-10.

24.Wang, X. dan Fu, Y. (2013). "Some Characterizations of the Cobb-Douglas and CES Production Functions in Microeconomics". Abtract and Applied Analysis, pp. 1-6.

25.Wardono, B., Fauzi, A., Fahrudin, A., dan Purnomo, A.H. (2015). "Total Faktor Produktivitas dan Indeks Instabilitas Perikanan Tangkap: Kasus di Pelabuhan Ratu, Jawa Barat". Jurnal Sosial Ekonomi Kelautan dan Perikanan, Vol. 10, No. 1, 35-46.

26. Widiyawati dan Setiawan. (2015). "Analisis Faktor-Faktor yang Mempengaruhi Tingkat Produksi Padi dan Jagung di Kabupaten Lamongan". Jurnal Sains dan Seni ITS, Vol. 4 No.1, pp. 2337-3520.

27.Wirawan, K.A., Susrusa, I.K.B., dan Ambarawati, I.G.A.A. (2014). "Analisis Produktivitas Tanaman Padi di Kabupaten Badung Provinsi Bali”. Jurnal Manajemen Agribisnis, Vol. 2 No. 1, pp. 76-90. 